\title{
O QUE AS LIÇÓES DE HISTÓRIA ENSINAM SOBRE A ÁFrICA? REFLEXÓES ACERCA DAS REPRESENTAÇÓES DA HISTÓRIA DA ÁFRICA E DOS AFRICANOS NOS MANUAIS ESCOLARES BRASILEIROS E PORTUGUESES
}

\author{
Anderson Ribeiro Oliva ${ }^{* *}$
}

\section{Resumo}

As imagens que povoam os cenários mentais dos estudantes brasileiros e portugueses sobre a África e os africanos foram construídas tanto por suas experiências de vida como pelas cenas que diariamente lhes são apresentadas pelos mais diversos meios de comunicação visual. $\mathrm{O}$ presente artigo objetiva identificar se parte da produçáo de livros escolares de História utilizados nas escolas da educação básica nesses espaços atlânticos contribuiu, de forma significativa ou não, para a construção de uma leitura mais adequada acerca daquele continente ou de suas trajetórias históricas.

Palavras-Chave: África, ensino da história africana, representações.

\section{What the lessons of history teach about Africa?}

\section{Abstract}

The images that are found in imaginary scenarios of Brazilian and Portuguese students about Africa and africans were built both by their life experiences as the scenes which are daily presented to them by various means of visual communication. This paper aims to identify whether History textbooks used in schools of basic education in these Atlantic areas contributes significantly or not to build a better read on that continent or on their historical trajectories.

KEY WORDS: Africa, teaching of African history, representations.

\section{IDEIAS INTRODUTÓRIAS}

Durante séculos, os africanos foram representados no imaginário Ocidental como seres inferiores e primitivos. Exemplos explícitos de tal comportamento mental e real podem ser encontrados nos mais diversos

Este texto foi apresentado originalmente como uma comunicação no VIII Congresso Luso-AfroBrasileiro, ocorrido em Coimbra, Portugal, no inverno de 2004. A versão agora divulgada sofreu modificaçôes e ajustes; no entanto, preservamos seu aspecto narrativo, com o objetivo de permitir a reprodução das ideias e o olhar panorâmico lançado sobre o assunto naquela oportunidade. $\mathrm{O}$ trabalho recebeu auxílio financeiro da Finatec.

** Professor Adjunto do Departamento de História da Universidade de Brasília. E-mail: olivaufg@ gmail.com 


\section{Revista Solta a Voz, v. 20, n. 2}

relatos - escritos ou imagéticos - deixados por viajantes, comerciantes, missionários, administradores e militares que transitaram pelo continente nas mais diversas temporalidades e espaços ${ }^{1}$.

Porém, não é preciso se distanciar muito no tempo para reconhecermos as limitaçóes e imperfeições de nossas referências e ideias acerca da África. Atualmente, em jornais e revistas, na televisão e no cinema, nas conversas e imagens que armazenamos na memória, a África e os africanos se confundem com velhos e resistentes estereótipos: regióes e pessoas marcadas pela miséria, pelas doenças, pelos conflitos étnicos, pela instabilidade política, pela AIDS, pela fome, pela falência econômica. Quando não são essas as visões que inundam nossas mentes, são as da natureza selvagem e dos ambientes exóticos das savanas, florestas tropicais e desertos, locais povoados por seres também bastante estranhos, como leóes e girafas, ou ainda por populaçóes que, em um passado próximo, eram consideradas não humanas, como os Khoisans, vulgarmente conhecidos como Bosquímanos, ou os pigmeus.

Com relação às demais sociedades africanas, também circulam falsas definiçóes. Em muitos depoimentos, as pessoas revelam que suas leituras acerca dos africanos ainda estâo marcadas pela perspectiva de que eles seriam selvagens e ignorantes, de que carregariam hábitos e comportamentos primitivos, imagens estas que foram cristalizadas e divulgadas pela montagem dos "Impérios" europeus em África no final do século XIX. Porém, essa forma de ler a África não se limita ao período chamado de Colonial ou ao momento correspondente à expansão oceânica dos séculos XV e XVI. Também não é exclusividade de europeus ou americanos. Isso reforça a necessidade de identificarmos as representaçóes depreciativas acerca da África em nossas sociedades e de movermos esforços para alimentar as mentes de crianças, jovens e adultos com outras imagens africanas, que náo escondam as realidades trágicas encontradas no continente, mas que também não o reduza a elas ${ }^{1}$.

1 Acerca das representaçôes ou das ideias elaboradas sobre a África e os africanos, ver as seguintes abordagens: Cf. OLIVA, Anderson Ribeiro. Os africanos entre representaçōes: viagens reveladoras, olhares imprecisos e a invenção da África no Imaginário Ocidental. In: Em Tempo de Histórias, publicação do Programa de Pós-Graduação em História, PPG-HIS/UnB v. 9, p. 90-114, 2005; . Da Aethiopia à África: as idéias de África, do medievo europeu à idade moderna. In: Fênix (Uberlândia/MG), v. 5, p. 1-20, 2008.

Um olhar mais pontual sobre a presença das imagens elaboradas sobre os africanos e a África no Brasil contemporâneo pode ser encontrado nos seguintes artigos: OLIVA, Anderson Ribeiro. 
Levando em consideração o contexto apresentado, o presente trabalho tem como proposta central analisar a forma como alguns manuais escolares de História, utilizados nas escolas brasileiras e portuguesas, representam os africanos e qual o papel reservado à história da África, no que diz respeito às temáticas e aos conteúdos abordados. Sabendo que os livros didáticos são elementos de fundamental relevância no modelo de ensino adotado por grande parte dos países de língua portuguesa que se comunicam pelo Atlântico e que têm um papel central na formação intelectual de suas populaçóes, não podemos desconsiderar seu poder de construir ou desconstruir referências sobre os mais diversos temas. É claro que esse poder é muito menor do que o da mídia ou das imagens que nos chegam pela Internet ou pela televisão e que cercam nossos estudantes, mas não deixa de ser uma possibilidade de mudança de olhares sobre os africanos e a história da África².

Para atingir nossos objetivos, percorreremos duas trilhas em nosso texto. A primeira servirá apenas como um reforço de retórica sobre os apontamentos iniciais. Tivemos a preocupação de percorrer, como já fizeram muitos outros pesquisadores, a história das representaçóes acerca da África e de suas populações, da Antiguidade aos dias de hoje. É evidente que, pelo longo espaço temporal abordado, não foi possível fornecer mais do que notícias superficiais sobre um vasto e heterogêneo conjunto de imagens e comportamentos. Na segunda parte, nossa preocupação foi con-

A Invençāo da África no Brasil: os africanos diante dos imaginários e discursos brasileiros dos séculos XIX e XX. In: Revista África e Africanidades, v. 1, p. 1-27, 2009; . Notícias sobre a África: representaçôes do continente africano na revista VEJA (1991-2006). In: Revista Afro-Ásia (UFBA), v. 38, p. 141-178, 2008; SANSONE, Livio. Da África ao Afro. Uso e abuso da África entre os intelectuais e a cultura brasileira durante o século XX. In: Revista Afro-Ásia, n 27, p. 249269, 2002.

2 Não ignoramos o intenso e complexo debate que envolve a produçáo e a leitura dos livros didáticos. No entanto, para os objetivos do presente artigo seria desgastante para o leitor tratar o tema de forma superficial. Indicamos, entre outras referências, as seguintes abordagens do tema: CASSIANO, Célia Cristina de Figueiredo. Aspectos políticos e econômicos da circulaçăo do livro didático de História e suas implicaçóes curriculares. In: História, São Paulo, v. 23, 1-2, p. 33-48, 2004; MACEDO, José Rivair. História e livro didático: o ponto de vista do autor. In: GUAZZELLO, Cezar Augusto Barcellos et al. (Orgs). Questóes de Teoria e Metodologia da História. Porto Alegre: EDUFRG, 2000, p. 289-301; MUNAKATA, Kazumi. História que os Livros Didáticos contam, depois que acabou a Ditadura no Brasil. In: FREITAS, Marcos Cezar (org.). Historiografia brasileira em perspectiva. São Paulo: Contexto, 2001, p. 271-298; VILLALTA, Luiz Carlos. O livro didático de história no Brasil: perspectivas de abordagem. In: Pós-História, Revista de PósGraduação em História (Unesp), Assis/SP, v. 9, p. 39-59, 2001. 
textualizar o uso dos manuais escolares nos sistemas de ensino em questão e, como esforço maior, analisar alguns manuais no Brasil e em Portugal que abordaram a história da África. Esperamos que seja uma boa contribuição para tão importante debate.

\section{IDEIAS E REPRESENTAÇÓES SOBRE OS AFRICANOS no Brasil e em Portugal}

No início do texto, alertávamos para os descuidos imaginários e para a postura inadequada na forma de tratar a África e os africanos, presentes em grande parte do mundo Ocidental. Para exemplificarmos tal comportamento, deixemos momentaneamente de lado as interpretaçóes elaboradas em outros espaços e tempos que não o presente e as experiências vividas no Brasil e em Portugal.

No Brasil encontramos um quadro de relações "raciais" bastante comentado por teóricos e políticos e profundamente ambíguo. Ao lado de uma realidade socioeconômica que se prontifica a revelar as desigualdades entre as populaçóes branca e negra de nossa sociedade - em anos de escolaridade, em número de pessoas com graduação ou pós-graduação, em valores dos salários, em estatísticas de criminalidade -, coexiste a falsa crença na democracia racial. Não é mais aceitável acreditar que a miscigenação ocorrida entre os grupos que aqui foram colocados em contato tenha esvaziado o dado racial nas relaçóes humanas e muito menos eliminado o racismo ${ }^{3}$. Com este cenário, não é de se estranhar o desinteresse, pelo menos de uma grande maioria, acerca da história da África.

Se por aqui é clara a situação de desprestígio e desigualdade econômica em que se encontra grande parte da população afrodescendente, em Portugal o quadro náo é diferente. Com uma onda migratória significativa no período posterior ao das independências dos países africanos de língua oficial portuguesa, que se acentuou muito

3 De fato, o assunto recebe um conjunto extenso e revelador de recortes. Para conferência, consultar o excelente artigo de SCHWARCZ, Lilia Moritz. Nem preto, nem branco, muito pelo contrário: cor e raça na intimidade. In: SCHWARCZ, Lilia Moritz (org.). História da vida privada no Brasil, vol. IV. São Paulo: Companhia das Letras, 2000, p. 173- 244. 
nos últimos vinte anos, existe hoje em Portugal um contingente formado por milhares de africanos, para não falar nos luso-africanos.

Quase sempre, esses imigrantes, legais ou ilegais, ocupam os postos de trabalho de menor relevância na escala da remuneração e do status profissional. É comum também o fato de habitarem os bairros periféricos e menos valorizados de algumas cidades, como Lisboa. Para além dos dados socioeconômicos, também é inquestionável a situação de desprestígio e preconceito com que convivem diariamente ${ }^{4}$. Com relação ao interesse pelos estudos africanos, a maior diferença com o quadro encontrado no Brasil é que os laços de dominação política, recentemente desfeitos, fizeram com que a África aparecesse de forma mais intensa, nas investigaçôes acadêmicas, como um apêndice do Estado Colonial português. Não que isso significasse um conhecimento menos deturpado sobre a África, já que, não raro, tais estudos reforçam, em alguma dimensão, o sentimento de superioridade europeia sobre as populaçooes e os países do continente africano. Porém, nos vários centros de estudos africanos, as publicaçóes têm crescido, assim como vários pesquisadores têm se destacado no cenário internacional com pesquisas qualificadas e elogiáveis.

Nos dois países, um conjunto de imagens é reprisado em nossas mentes e falas: os africanos e seus descendentes são tratados como se fossem atrasados, preguiçosos, incapazes para algumas tarefas, sem educação, desorganizados, inferiores. O mais revelador disso é que esse conjunto imagético não é fruto apenas das relaçóes contemporâneas entre europeus, americanos e africanos, pois possuem uma longa historicidade.

Pode-se afirmar também que a África e os africanos, quando entendidos de forma conceitual, são invençôes estrangeiras. É claro que essas identidades foram apropriadas e modificadas pela ação autônoma de homens e mulheres das mais diversas regióes em África, sendo correto afirmar que a identidade de "africano", aquela que reúne as sociedades e milhóes de pessoas abaixo do Saara, foi apenas muito recentemente inventada ou incorporada.

Evidencia-se, dessa constatação, que os filtros culturais usados pelos europeus e pelas demais sociedades não africanas para observar a

4 Acerca da questão, consultar o seguinte artigo: OLIVA, Anderson Ribeiro. De indígena a imigrante. O lugar da África e dos africanos no universo imaginário português dos séculos XIX ao XXI. In: Sankofa. Revista de História da África e de Estudos da Diáspora Africana, v. 3, p. 32-51, 2009. 


\section{Revista Solta a Voz, v. 20, n. 2}

África estavam marcados por manchas que impediam ou deformavam a capacidade de observação, gerando uma perspectiva etnocêntrica que os tornava incapazes de enxergar as singularidades e qualidades do continente negro.

Apesar da ativa participaçáo dos africanos nos processos de invenção e reinvenção de suas identidades, a influência extra-africana na forma de denominar e tratar a África é algo ainda muito marcante. Os nomes que, ao longo de séculos, surgiram para fazer referência à terra e aos seus habitantes foram criaçóes de fora, quase sempre de europeus ou muçulmanos. Essas tentativas para tentar identificar a África, realizadas por diversas sociedades e em diversas temporalidades, revelam, acima de tudo, que o que marcou a relação entre os "africanos" e os não "africanos" foram o distanciamento, as diferenças, o estranhamento e a comparação negativa.

Percebamos como isso ocorreu e ainda ocorre. Para facilitar nossa incursão sobre essa trajetória, a dividimos em sete momentos, abaixo apresentados ${ }^{5}$ :

1. $\mathrm{Na}$ Antiguidade, a África, chamada de Etiópia, era um território limitado pelas areias do Saara, possuía temperaturas que corrompiam suas populaçôes (denominadas etíopes) e recebia como principal elemento diferenciativo de suas gentes a cor negra. Os relatos de Heródoto e Cláudio Ptolomeu são testemunhos dessas visões.

2. No Medievo, associaçóes com a teoria camita e a fusão da cartografia da Antiguidade com a cosmologia cristã relegaram a África e os africanos às piores regióes da Terra. Segundo os textos bíblicos, Cam, um dos filhos de Noé, foi punido por flagrar seu pai nu e embriagado. Como punição, seus descendentes deveriam se tornar servos dos descendentes de seus irmãos. Da mesma maneira, as formulaçóes dos espaços celestiais paraíso, purgatório e inferno - criaram a necessidade de projetá-los sobre os espaços terrestres, cabendo à África a associação com as paisagens

5 Esses momentos e suas ideias de África encontram um enfoque mais extenso e revelador nos seguintes trabalhos: OLIVA, Anderson Ribeiro. Liçōes sobre a África: diálogos entre as representaçôes dos africanos no imaginário Ocidental e o ensino da História da África no Mundo Atlântico (1990-2005). 2007. Tese (Doutorado em História Social) - Instituto de Ciências Humanas, Universidade de Brasília, p. 16-90, 2007; MUDIMBE, Valentin. The invention of Africa. Bloomington. Indianapolis: Indiana University Press, 1988; Indianapolis: Indiana University Press, 1994. The idea of Africa. Bloomington; 
infernais. Soma-se, por fim, a esses elementos, a sentença de que a cor negra simbolizava a ausência da moral e do bem.

3. Com as Grandes Navegaçóes, o imaginário dos navegantes teria, de forma intensa, acentuado as leituras fantásticas e depreciativas acerca da África. Os temores sobre o Mar Oceano e a região abaixo do Equador iriam alimentar as elaborações e representações dos europeus sobre os africanos. Monstros, terras inóspitas, seres humanos deformados, imoralidades, regiōes e hábitos demoníacos se tornaram elementos constantes nas descrições de viajantes, aventureiros e missionários.

Porém, um elemento novo se acrescenta a essa fórmula de enxergar o Outro: os contatos ocorrem agora ao sul do Equador, na região da África subsaariana banhada pelo Atlântico e o Índico. Os africanos de pele negra, anteriormente chamados etiopes, seriam a partir de então intitulados guinéus, sudaneses e, por fim, africanos.

As representaçôes sobre as populaçóes e o meio ambiente sofreriam a tendência de relacionar aquele mundo às imagens da devassidão, da barbárie, do canibalismo e da natureza fantástica. As práticas antropofágicas aparecem em alguns relatos e em várias imagens.

4. Entre os séculos XVI e XIX, um dos principais elementos integrantes das relaçóes estabelecidas entre as margens do Atlântico seria o tráfico de escravos. A grande diáspora africana foi responsável pela elaboração de diversas culturas negras pelo Ocidente. No entanto, a condição de cativos somente potencializaria os preconceitos e as representaçóes negativas sobre os africanos, agora não somente em África e na Europa, mas também na América.

5. No século XIX, os preconceitos anteriores articulam-se às açôes de conquista sobre o continente, patrocinadas pelas potências europeias, e às teorias científicas, oriundas das concepçóes do darwinismo social e do determinismo racial, que colocaram os africanos nos últimos degraus da evolução das "raças" humanas. Infantis, primitivos, tribais, incapazes de aprender ou evoluir, os africanos deveriam receber a benfazeja ajuda europeia por meio das intervençóes imperialistas. Os escritos dos viajantes e aventureiros se impregnam desse viés.

6. Ao longo da primeira metade do século XX, a ação das metrópoles europeias ocorreria no sentido de explorar ao máximo os territórios 
e suas populaçóes. A criação de protetorados ou de colônias efetivas seria responsável por um problemático processo de invenção de fronteiras e de insistentes tentativas de ocidentalizar as populaçóes do continente. Sob a tênue justificativa propagada e difundida por figuras como Rudyard Kipling, os europeus insistiram na ideia de estar cumprindo em África uma ação humanitária e civilizatória, com o conhecido argumento de que a presença na região seria um fardo para o homem branco.

7. No período pós-Segunda Guerra Mundial, intensificam-se os movimentos africanos pela independência das regióes dominadas pelos europeus. No intervalo de anos que se estendem de 1950 a 1975, a grande maioria dos países africanos estava livre da dominação europeia. Porém, as condiçóes socioeconômicas e políticas presentes no continente em nada contribuiriam para mudar o imaginário circulante sobre a África. Nos últimos anos, a exclusão do continente do processo de globalização e das redes econômicas internacionais mais lucrativas, o flagelo da fome e da AIDS, as ondas de imigração africana para a Europa e as instabilidades políticas reforçaram as falsas crenças sobre a África. Nos jornais escritos, na televisão, no cinema, na Internet, encontramos quase sempre um mesmo conjunto de imagens e referências sobre a África e os africanos. E é basicamente esse o único contato que crianças e jovens brasileiros e portugueses mantêm com a região.

\section{Os AFRICANOS E A HISTÓRIA DA ÁFRICA NOS MANUAIS ESCOLARES DE HistóRIA}

Ao saber que a frequência à escola é obrigatória ${ }^{6}$ no Brasil - no que chamamos de Ensino Fundamental, com duração de nove anos ${ }^{7}$ - e em Portugal - no Ensino Básico, também com duração de nove anos - podemos supor que o material didático produzido e utilizado nas escolas é um instrumento de grande importância para a construção do conhecimento histórico elaborado por alunos e professores nessas áreas. Levando-se em consideraçáo

6 Nos anos 1990, nas regióes citadas - Brasil/Portugal - essa obrigatoriedade foi sendo aos poucos efetivada em números reais. Os índices de alunos matriculados no Ensino Fundamental no Brasil e no Ensino Básico em Portugal correspondem à grande parte da populaçáo em idade escolar nos países em questão.

7 No período eleito para investigação, a duração do Ensino Fundamental brasileiro era de oito anos. 
esse dado e a precária situação econômica de parcela dos habitantes do Brasil e de Portugal, com seus contingentes de desempregados e subempregados, seria correto pensar que, em muitos casos, o único contato com o ensino da história nesses países será realizado na escola e muitas vezes pelo manual escolar.

Em nossa investigação, analisamos alguns manuais elaborados a partir da década de 1990, voltados para o que no Brasil correspondia, até 2007, aos quatro últimos anos do Ensino Fundamental ( $5^{\mathrm{a}}$ a $8^{\mathrm{a}}$ série), e em Portugal, ao último ano do segundo ciclo e a todo o terceiro ciclo do Ensino Básico $\left(6^{\circ}\right.$ ao $9^{\circ}$ ano).

Podemos adiantar que, tanto no Brasil como em Portugal, apenas um número muito pequeno de livros, das coleçóes de livros didáticos compulsadas pela pesquisa, possuía capítulos ou tópicos específicos sobre a história da África. Na maioria das obras, a África é retratada de forma secundária e dependente das demais temáticas. $\mathrm{O}$ uso de uma bibliografia limitada, no que se refere à produção historiográfica especializada nos estudos africanos, criou também sérios obstáculos aos autores dos manuais observados. Percebamos como se apresenta a utilização dos manuais nas escolas lusófonas brasileiras e portuguesas ligadas pelo Atlântico.

\section{A África e os LIVRos didáticos No BrasiL}

Convivendo com os bancos escolares desde 1982, ora como aluno, ora como professor, é interessante perceber que a história da Europa sempre possuiu um papel de destaque em nossos livros e currículos. À história da América concedem-se alguns capítulos, e à história indígena e do Oriente, quando aparecem, são oferecidas apenas breves e fragmentadas notícias, mesmo que ocupando um "capítulo inteiro". Com relação à África, ela aparece muitas vezes apenas como um apêndice passivo da história comercial europeia. Nem o Egito parece ser africano - ele é muito mais Mediterrânico ou do Médio Oriente do que africano propriamente dito.

Esse enfoque em nada auxilia a (des)construção do anteriormente citado imaginário preconceituoso e deturpado que circula na mídia e em nossas referências mentais sobre a história da África. Outro dado inquestionável para professores e alunos é que as histórias da escravidão, dos africanos e dos afrobrasileiros se confundem em nossos olhares para o passado. Ou seja, os africanos chegam até os bancos escolares brasileiros como escravos e impregnados pelos estereótipos. 


\section{Revista Solta a Voz, v. 20, n. 2}

Tais questóes nos fizeram percorrer as páginas de alguns livros escolares brasileiros ${ }^{8}$ que, a partir da segunda metade da década de 1990, têm tido a preocupação de incluir entre seus volumes capítulos específicos sobre a história da África, com enfoque específico ao período correspondente ao intervalo de tempo que se estende do século VIII ao XIX. Alguns pontos comuns foram encontrados entre os desacertos e acertos dos autores. Façamos um breve balanço, lembrando que nem todos os aspectos aqui citados são comuns aos textos, mas sim frutos de um panorama geral desses manuais.

- Existe clara tendência, entre os volumes analisados, de dedicar um número significativamente menor de páginas à história da África, se comparada a outras temáticas. Percebe-se uma clara perspectiva eurocêntrica tanto nos programas de História como nos próprios manuais. Por exemplo, enquanto os capítulos que tratam de temas como Feudalismo, Absolutismo Monárquico, Renascimento Cultural e Construção do Pensamento Moderno Ocidental ocupam entre 15 e 20 páginas e trazem vasta bibliografia, a História da África quase sempre é abordada em um único capítulo, que varia de 10 a 13 páginas, e com uma literatura de apoio restrita.

Por falta de conhecimento ou de interesse, percebe-se um grande desequilíbrio no tratamento das civilizaçôes e história do Ocidente e da África. Fora os capítulos específicos sobre a África, anterior aos europeus, ela transita em outras partes dos volumes. Nos capítulos que tratam da Expansão Marítima dos séculos XV e XVI, o continente é retratado ora como um obstáculo a ser superado para atingir o lucrativo mercado de especiarias do Oriente, ora como uma fonte de riquezas e lucros com o comércio do ouro, marfim e escravos.

- Ao analisar os efeitos e as características da escravidão e do tráfico negreiro para as populaçóes africanas, os textos, com raras exceçóes, revelam um grande descompasso com as novas pesquisas historiográficas. Sobre as referências ao uso da escravidão na África e na América e das motivaçóes econômicas que alimentaram o tráfico negreiro, algumas posturas incomodam.

Alguns autores não fazem alusão explicativa à escravidão tradicional africana, como se a escravidão fosse uma invenção árabe ou europeia na-

8 Para o presente trabalho, analisamos os seguintes livros: DREGUER, Ricardo; TOLEDO, Eliete. História: cotidiano e mentalidades, 7 ed. 2000; SCHMIDT, Mario. Nova História Crítica, $6^{a}$ série, 1999. 
quele continente. Mesmo sabendo das profundas diferenças entre a escravidão praticada pelos africanos e aquela utilizada sob influência dos árabes na península arábica, ou dos europeus na América, seria fundamental um comentário sobre o tema.

Ao tentar situar os alunos acerca das relações existentes entre as práticas materiais e as mentalidades de certos períodos, algumas análises se revestem de um perigoso anacronismo. Um dos autores citados afirma que mesmo sendo apoiada pela Igreja, pelos governos, comerciantes, políticos, fazendeiros e pela mentalidade da época, a escravidão foi de alguma forma injusta em sua própria essência e nunca poderia ter sido justificada (Cf. Schmidt, 1999, p. 102-213). Soma-se a esse quadro o uso pouco adequado de imagens que ilustram africanos e escravos no Brasil em condição de submissão e de punição. Nelas é reproduzido o estereótipo do negro passivo e sofredor.

Quase não existem menções aos africanos traficantes ou às formas de escravização usadas em África. Para alguns autores, somente os comerciantes portugueses, espanhóis, ingleses e brasileiros fizeram parte das redes de lucro oriundas de tal atividade. A participação de africanos no comércio de homens é, assim, ignorada.

- Nos livros didáticos que não concedem abordagens específicas à história africana, um dos equívocos mais comuns encontrados é o de fazer referência à África apenas a partir do tráfico de escravos para a América do século XVI em diante. Seria como se o continente náo tivesse uma história anterior à escravidão atlântica. Nesses casos, a África é representada em mapas dividida em duas áreas populacionais, de onde sairiam os escravos sudaneses e bantos. As diversidades e complexidades das sociedades africanas são, dessa forma, ignoradas. Os estudantes, ao terem contanto com essa simplista leitura, podem transformar milhares de grupos étnicos e sociedades nesses dois amorfos e pouco explicativos conjuntos populacionais.

Outros autores procuram estabelecer nomenclaturas diversas, nas quais optam por eleger as regióes de embarque dos africanos escravizados como referência identitária: Guiné, Costa da Mina e Angola, por exemplo. Essas duas leituras parecem somar vozes às visóes que percebiam os africanos subsaarianos como membros de um conjunto homogêneo de populaçóes.

- Quando os autores dos livros analisados procuram citar as sociedades africanas estudadas, fazem uso de uma difundida ideia entre alguns 


\section{Revista Solta a Voz, v. 20, n. 2}

historiadores que se serviram de padróes e referências europeias para explicar o que se observava em África. Neste sentido, encontrar os grandes “impérios", as grandes construçôes e as esplendorosas obras de arte tornou-se quase que uma obsessão. Porém, se a África era e é uma região de grande autonomia, capacidade criativa e de fecunda participação na História da humanidade, não seria preciso eleger padrôes europeus para sua legitimação.

Essa crítica já foi feita, com grande pontualidade, a alguns daqueles historiadores. Porém, os autores parecem desconhecê-la, pois é justamente esse o critério eleito para selecionar o que será estudado. Como se os "pequenos" grupos não tivessem relevância, ou porque, diante da impossibilidade de atentar para os milhares de grupos que se espalham pela África, a seleção ocorreu se espelhando na história da Europa: o estudo das grandes civilizaçóes ou reinos. Não é isso que realizamos com relação ao ensino da História? Não elegemos a Civilização Grega, o Império Romano, o Império Bizantino, a Civilização Muçulmana? Não ignoramos a existência em África de organizaçôes políticas ou sociais, com grandes semelhanças às europeias ou americanas, mas é preciso que se demonstre e enfatize suas singularidades e especificidades.

- Com relação à forma de denominar ou identificar as sociedades africanas, o uso de alguns termos ou conceitos, como nação, países, reinos e impérios, parece ser por demais impreciso, diante do grande suporte que as pesquisas antropológicas e históricas já deram sobre o assunto. Somase a isso uma abordagem muitas vezes simplista e restrita às descriçóes da economia ou da formação política de reinos como o da Núbia, de Gana, do Mali, do Kongo, do Zimbábue e do Ndongo e de sociedades como a dos hauças, iorubás, ibos, askans e ajas. Fica evidente que os autores encontram dificuldades em tratar ou denominar os grupos africanos que não se organizavam em Estados e confundem ainda mais os alunos ao usar termos ou definiçóes que se ajustam mais especificamente ao contexto histórico europeu ou de outras regióes. Não que não possam ser aplicados no entendimento da África, mas, se utilizados, devem ser contextualizados.

- Outra tendência comum é enfatizar apenas algumas regióes da África Ocidental ou Central-Ocidental, ignorando outros espaços africanos. Nas descriçóes, os autores muitas vezes abordam acertadamente a relevância da metalurgia, as invençóes no domínio da grande agricultura 
e as intensas dinâmicas dos circuitos comerciais africanos, que envolviam diversas atividades econômicas de várias regiôes do continente. Porém, ao concentrar seus recortes nessas grandes áreas, os textos acabam por não contemplar a intensa diversidade e multiplicidade das experiências históricas em África.

- Aos que se referem às cosmologias africanas, em poucos momentos os livros atentam para uma abordagem explicativa da relação entre as diferentes percepçóes e definiçốes daquilo que os ocidentais chamam de Religião para as elaboraçóes africanas sobre a questão. A literatura existente sobre o pensamento tradicional religioso africano oferece um rico subsídio para este debate, fundamental para relativizar o universo africano e demonstrar como suas estruturas de explicação das relaçóes sociais e de vida são diferentes das ocidentais.

- No aspecto iconográfico, os livros apresentam, quase sempre, conjuntos reveladores de imagens: mapas que fogem das representaçóes cartográficas tradicionais; fotografias de mesquitas em Mopti e Djenee ou da cidade de Tombuctu, no Mali; esquemas e imagens do Grande Zimbábue; ilustraçóes ou fotografias de esculturas feitas pelas mais diversas sociedades africanas. Todos esses recursos visuais são importantes instrumentos na apresentação das formas arquitetônicas, das religiosidades, das artes e das filosofias africanas, quebrando com velhos e insistentes estereótipos.

Há também autores que, em válida iniciativa, chamam a atenção dos alunos para as representaçóes feitas dos africanos pelos europeus: a mudança da fisionomia dos africanos, de seus gestos, roupas e comportamentos, que recebem feiçóes europeias, é sintomática da forma como os europeus enxergavam a África.

- Com relaçáo ao uso da historiografia africana ou das investigaçóes mais recentes acerca do continente, as bibliografias citadas, apesar de conterem nomes e obras importantes, são ainda bastante restritas, se comparadas à difusão de estudos e pesquisas sobre a história da África nos últimos vinte anos. A presença dos trabalhos de Basil Davidson, Roland Oliver e Joseph Ki-Zerbo demonstra o contato com a vertente de estudos efetuados até a década de 1970. Já a citação da obra de Alberto da Costa e Silva revela um pequeno contato com os novos estudos, porém a referência é ainda insuficiente. 


\section{Revista Solta a Voz, v. 20, n. 2}

\section{A África e os manuais em Portugal}

Se no Brasil encontramos o quadro descrito acima, em Portugal a perspectiva é muito mais preocupante. Dos vários manuais compulsados, apenas dois traziam algum tipo de informação mais específica sobre a história da África, quase sempre em subtítulos ou tópicos dentro de alguns capítulos. De uma forma geral, encontramos problemas muito parecidos com os dos manuais brasileiros, com agravantes que se relacionam com as representaçôes que circulam sobre os africanos e a África, especificamente no imaginário português contemporâneo. Vejamos quais foram as maiores limitaçôes ou imprecisóes percebidas na pesquisa ${ }^{9}$ :

- Os silêncios sobre a história da África são tão acentuados que, nos capítulos que abordam a história do Egito Antigo, a palavra África não foi encontrada nenhuma vez e o termo africano, apenas uma. Reforça-se uma perspectiva de alocar a civilização egípcia fora do continente negro, relacionando-a muito mais com as civilizaçóes e sociedades do Oriente Próximo e da Europa Mediterrânea.

- Outra abordagem comum associa os africanos à Expansão Marítima Europeia dos séculos XV e XVI. A África surge inicialmente como um depositário de riquezas que atraem os europeus - ouro, escravos e especiarias africanas -, e de troca de mercadorias manufaturadas europeias. Posteriormente, figura como simples obstáculo territorial, ou ainda ponto de escala para que se pudesse atingir o sonhado mercado de produtos orientais.

- Sobre as dificuldades encontradas pelos portugueses no périplo africano ou no estabelecimento do tráfico negreiro, o elemento humano do continente só é lembrado quando se transforma em mercadoria, ou seja, quando se torna escravo. Os autores concentram suas informaçóes nos obstáculos climáticos e tecnológicos e negligenciam as diversas resistências interpostas por parte das populaçôes africanas à passagem europeia, à escravização ou pela disputa do tráfico. O contato com os reinos ou espaços africanos, como a cos-

9 Os livros analisados foram: AZEVEDO, Ana Maria. Nova História Viva. $8^{\circ}$ ano de escolaridade. Lisboa: Plátano Editora, 1993; LASBARRÈRES, Eva; FÉLIX, Noémia; HENRIQUES, Vítor. Conhecer o passado, Compreender o Presente. História de Portugal. 6 ano. Lisboa: Texto Editora, 1991; NEVES, Pedro Almiro. À descoberta da História 7. $7^{\circ}$ ano de escolaridade. Porto: Porto Editora, 1991. 
ta angolana, as expediçóes pelo Rio Zaire ou as relaçóes iniciais com o reino do Congo servem apenas para enaltecer o papel desempenhado por alguns navegadores lusitanos na aventura de cruzar oceanos e chegar ao Oriente, e não para citar experiências ou características do continente e de suas gentes.

- Quando os autores procuram conceder um pouco mais de atenção à história da África, utilizam títulos como Os Portugueses na África Negra. Ora, parece a confirmação de uma velha máxima sobre a história do continente, quando se afirmava que os africanos não tinham história, a não ser aquela iniciada com a presença europeia em suas terras. Seriam, portanto, os europeus, os promotores da história em África, ou, na melhor das hipóteses, a história dos africanos anterior aos europeus não interessa ao público escolar português.

- Em alguns livros, encontramos uma perigosa forma de denominar as populaçôes africanas. A "África Negra" seria, para esses autores, a parte do continente habitado por populaçóes de raça negra. Ao usar esse tipo de nomenclatura ou conceito, autores, professores e alunos estão se aproximando de armadilhas teóricas e de comportamento preocupante. É muito provável que as velhas crenças da superioridade da raça branca sejam indiretamente levantadas ao se reforçar essa ultrapassada classificação. Visões como a da incapacidade intelectual, das práticas selvagens e primitivas associadas à "raça negra" nos séculos anteriores voltam à tona.

- Para fazer referência às sociedades africanas, são empregados termos como tribos ou grupos nômades. Ao mesmo tempo, velhos e imprecisos nomes são mencionados, por exemplo, chamar os povos africanos de sudaneses, bantos, pigmeus, ignorando a multiplicidade de sociedades e de grupos étnicos que habitavam a África. A não presença da escrita em grande parte da África Negra é mencionada, reforçando a perspectiva de que foram os europeus ou os muçulmanos que introduziram a tradição escrita na região subsaariana do continente. Porém, o potencial de preservar e contar a história presente na tradição oral quase sempre é ignorado.

- Sobre o tráfico negreiro e suas consequências, os livros citam a possível depressão demográfica que o comércio de milhóes de africanos pelo Atlântico teria causado no continente, algo que deixou de ser consenso na historiografia especializada há vários anos. As trocas entre as culturas americanas e africanas também aparecem com frequência. Alguns chegam a afirmar, com razão, que a América foi africanizada. Porém, quando comentam a 


\section{Revista Solta a Voz, v. 20, n. 2}

relação cultural entre europeus e africanos, a via torna-se de mão única - Europa/África. Somente a influência europeia na África é mencionada, como se nenhuma contribuição ou elemento africano tivesse chegado à Europa. Ainda comentando o tráfico, em um dos livros encontramos a afirmativa de que ele foi realmente uma "página negra" na história da humanidade, como se o trocadilho não estivesse carregado de preconceitos e equívocos.

- Como ponto positivo, encontra-se a citação da presença de vários impérios ou reinos africanos, como os de Gana, Mali, Songhay, Benin e Monomotapa. Mas em nenhum momento os autores alertam para os diferentes empregos que esses conceitos e categorias - cunhados a partir das experiências históricas europeias - precisam receber para os estudos africanos. Algumas imagens, com breves comentários, também revelam faces do continente, permitindo que os alunos tenham contato com imagens positivas sobre a África.

\section{Últimas Palavras}

Acredito que, percorrido esse breve caminho sobre a abordagem da história da África nos bancos escolares atlânticos, fica evidente a urgência de repensarmos o ensino e as pesquisas sobre a temática. As limitaçóes transcendem os preconceitos existentes na sociedade brasileira e portuguesa, e se refletem de certo modo no descaso da academia, no despreparo de professores e na desatenção de editoras pelo tema.

É óbvio que muito se tem feito pela mudança desse quadro. Louve-se, nesse sentido, a ação de alguns núcleos de estudo e pesquisa em história da África montados no Brasil e em Portugal. Enalteça-se a iniciativa legal do governo e do movimento negro no Brasil e de alguns historiadores atentos à questâo nos dois lados do Atlântico. Ressalte-se a ação de algumas instituiçóes e professores que têm promovido palestras, cursos de extensão e de pós-graduação em História da África. Porém, ainda existem grandes lacunas e silêncios. A obrigatoriedade de se estudar África nas graduaçóes, a abertura do mercado editorial - traduçóes e publicaçóes - para a temática, até a maior cobrança de História da África nos vestibulares no Brasil e nos currículos dos dois países são medidas que tendem a aumentar o interesse pela história do continente ao qual o Atlântico nos liga. Talvez assim, em um esforço coletivo, as coisas possam mudar. 


\section{REFERÊNCIAS}

APPIAH, Kwame Anthony. Na casa de meu pai. Rio de Janeiro: Contraponto, 1997.

CALDEIRA, Arlindo Manuel. A História de África no Ensino não Universitário em Portugal. In: Actas do Colóquio Construção e ensino da história da África. Lisboa: Linopazas, 1995. p. 545-553.

CASTRO, Rui Vieira de et al. Manuais escolares: estatuto, funçôes, História. Actas do I Encontro Internacional sobre manuais escolares. Porto: Universidade do Minho, 1999.

FANON, Frantz. The wretched of the earth. Harmondsworth, Penguin, 1983.

GILROY, Paul. O Atlântico Negro. Rio de Janeiro, UCAM: Editora 34, 2001.

HORTA, José da Silva. A representação do africano na literatura de viagens, do Senegal a Serra Leoa (1453-1508). Mare Liberum, Lisboa, no 2, 1991, p. 209-339.

KAPPLER, Claude. Monstros, demônios e encantamentos no fim da Idade Média. São Paulo: Martins Fontes, 1994.

KI-ZERBO, Joseph. História Geral da África: metodologia e pré-História da África. Vol. IV. São Paulo: Ática; Paris: Unesco, 1982.

LOPES, Carlos. A Pirâmide Invertida - historiografia africana feita por africanos. In: Actas do Colóquio Construção e Ensino da História da África. Lisboa: Linopazas, 1995.

LOVEJOY, Paul E. A escravidão na África: uma história de suas transformaçôes. Rio de Janeiro: Civilização Brasileira, 2002.

M’ BOKOLO, Elikia. África Negra História e Civilizaçôes. Até ao Século XVIII. Lisboa: Vulgata, 2003.

NETO, Maria da Conceição. Professores e História de África: as intençôes e a realidade. In: Actas do Colóquio Construção e ensino da história da África. Lisboa: Linopazas, 1995, p. 537-553. 
OLIVA, Anderson Ribeiro. Os africanos entre representaçóes: viagens reveladoras, olhares imprecisos e a invenção da África no Imaginário Ocidental. Em tempo de Histórias, Brasília, n 9, ano 9, p. 90-114, 2005.

- O ensino da História africana. A presença da África nos manuais escolares brasileiros e portugueses. In: PANTOJA, Selma (org.). Identidades, Memórias e História em Terras Africanas. Luanda: Nzila, 2006, p. 137-167.

. Liçôes sobre a África: diálogos entre as representaçôes dos africanos no imaginário Ocidental e o ensino da História da África no Mundo Atlântico (1990-2005). 2007. Tese (Doutorado em História Social) - Instituto de Ciências Humanas, Universidade de Brasília, Brasília, DF, 2007.

PANTOJA, Selma; ROCHA, Maria José (orgs.). Rompendo Silêncios: História da África nos currículos da educação básica. Brasília: DP Comunicaçóes, 2004.

PROENÇA, Maria Cândida (org.). Um século de Ensino da História. Lisboa: Colibri, 2001.

THORNTON, John. A África e os africanos na formação do Mundo Atlântico, 1400-1800. Rio de Janeiro: Campus, 2003.

TINHORÃO, José Ramos. Os Negros em Portugal: uma presença silenciosa. Lisboa: Caminhos, 1988.

\section{Manuais escolares}

AZEVEDO, Ana Maria. Nova História Viva. $8^{\circ}$ ano. Lisboa: Plátano Editora, 1993.

DREGUER, Ricardo; TOLEDO, Eliete. História: cotidiano e mentalidades. 7 ed. São Paulo: Atual, 2000.

LASBARRÈRES, Eva; FÉLIX, Noémia; HENRIQUES, Vítor. Conhecer $o$ passado, Compreender o Presente. História de Portugal. $6^{\circ}$ ano. Lisboa: Texto Editora, 1991.

SCHMIDT, Mario. Nova História Crítica, 6 ed. São Paulo: Nova Geração, 1999. 